\title{
Relationships between bacteria and heterotrophic nanoplankton in marine and fresh waters: an inter-ecosystem comparison
}

\author{
Robert W. Sanders ${ }^{1}$, David A. Caron ${ }^{2}$, Ulrike-G. Berninger ${ }^{2}$ \\ ${ }^{1}$ Academy of Natural Sciences of Philadelphia, 1900 Benjamin Franklin Parkway, Philadelphia, Pennsylvania 19103-1195, USA \\ ${ }^{2}$ Department of Biology, Woods Hole Oceanographic Institution, Woods Hole, Massachusetts 02543, USA
}

\begin{abstract}
Despite differences in the species compositions and absolute abundances of planktonic microorganisms in fresh- and saltwater, there are broad similarities in microbial food webs across systems. Relative abundances of bacteria and nanoplanktonic protozoa (HNAN, primarily heterotrophic flagellates) are similar in marine and freshwater environments, which suggests analogous trophic relationships. Ranges of microbe abundances in marine and fresh waters overlap, and seasona! changes in abundances within an ecosystem are often as great as differences in abundances between freshwater and marine systems of similar productivities. Densities of bacteria and heterotrophic nanoplankton, therefore, are strongly related to the degree of eutrophication, and not salt per se. Data from the literature is compiled to demonstrate a remarkably consistent numerical relationship (ca 1000 bacteria: 1 HNAN) between bacterioplankton and HNAN from the euphotic zones of a variety of marine and freshwater systems. Based on the results of a simple food web model involving bacterial growth, bacterial removal by HNAN, predation on HNAN, and the observed relationships between bacterial and HNAN abundances in natural ecosystems, it is possible to demonstrate that bottom-up control (food supply) is more important in regulating bacterial abundances in oligotrophic environments while top-down control (predation) is more important in eutrophic environments.
\end{abstract}

\section{INTRODUCTION}

Heterotrophic microbial populations have been the focus of numerous investigations in marine and freshwater habitats during the past 2 decades. Most studies have concentrated on single environments and shortterm investigations. Based on these numerous studies it is clear that bacteria and their consumers are generally important components of energy flow and nutrient cycling in a wide variety of aquatic ecosystems (Azam et al. 1983, Porter et al. 1988, Caron et al. in press). Similarly, heterotrophic nanoplanktonic protists (2 to $20 \mu \mathrm{m}$ microorganisms, primarily flagellated protozoa) have been implicated as the major grazers of bacteria in most pelagic freshwater and marine communities (Güde 1986, Sanders \& Porter 1986, Coffin \& Sharp 1987, Wright et al. 1987. Hagström et al. 1988, Nagata 1988, Sanders et al. 1989, Wikner et al. 1990, Berninger et al. 1991a).

As large data sets on microbial abundance and production have emerged during the past few years, analyses have begun to focus on the mechanisms regulating heterotrophic microbial population densities in different environments, and the degree to which that regulation might differ between ecosystems. These attempts to model bacterial abundances and productivities have resulted, at some levels of examination, in remarkable similarities in the microbial processes of a diverse array of aquatic communities. For example, it has been demonstrated that bacterial abundances are positively correlated with chlorophyll concentrations, and bacterial productivities correlated with primary productivities, across a wide range of environments including freshwater and marine communities (Bird \& Kalff 1984, Cole et al. 1988, White et al. 1991). Cole et al. (1988) estimated that approximately $40 \%$ of the total primary productivity was consumed by bacteria in the euphotic zone of aquatic ecosystems ranging from highly oligotrophic to highly eutrophic. A subsequent analysis (White et al. 1991) with a larger data set has confirmed the relationships reported by Cole et al. (1988). No consistent differ- 
ences were observed between marine and freshwater systems in these studies, although it was suggested that temperature may affect bacterial production more in marine systems than in fresh water (White et al. 1991).

The cross-system correlations of bacterial production and abundance to factors related to substrate supply immediately raise a related question: 'Can bacterial abundance and productivity also be correlated with the density and grazing activity of bacterial consumers in different environments?' The existence of such correlations would require that the major consumers of bacteria are similar in all environments and that these bacterial consumers are themselves subject to similar mortalities (i.e. grazing pressures). As stated above, it would appear that nanoplanktonic protists are the major consumers in most (if not all) aquatic ecosystems. Other potentially important consumers of bacteria, however, do exist in freshwater and marine environments. Recent evidence has pointed to potentially important roles for cladocera, bacterivorous ciliates, mixotrophic algae, and bacteriophages in the removal of bacteria from aquatic ecosystems ( $E$. Sherr et al. 1986, Sanders \& Porter 1988, Bergh et al. 1989 , Pace et al. 1990, Proctor \& Fuhrman 1990). The extent to which the grazing activities of these other consumers might obscure a relationship between bacteria and heterotrophic nanoplankton (HNAN) is unknown.

Consumers of HNAN populations also may differ between environments of different trophic status or between fresh water and seawater. For example, ciliates and copepods consume nanoplanktonic flagellates in freshwater and marine systems, but cladocera and rotifers are much more common in freshwater and some estuarine systems than in oceanic waters. On the other hand, pelagic tunicates (salps, doliolids and larvacea) and sarcodines (foraminifera, radiolaria and acantharia) may be important consumers of bacterivorous flagellates in marine but not freshwater ecosystems. There is no a priori reason to believe that the strong correlation that exists between phytoplankton and bacteria will also exist between bacteria and HNAN when data sets from diverse aquatic ecosystems are compared.

Nonetheless, we have summarized data (largely from the literature) that demonstrate a strong positive correlation between the abundances of bacteria and HNAN, irrespective of salinity, over a range of environments that vary from highly oligotrophic to hypereutrophic. There was a large variability (up to 100fold) in the abundance of HNAN at any particular bacterial density, presumably due to differences in geographic location, season, depth (within the euphotic zone) and predator-prey oscillations as well as possible methodological differences between investi- gations. Over the complete data set, however, absolute densities of bacteria and HNAN increased ca 3 to 4 orders of magnitude. Higher bacterial and HNAN densities were established and maintained in systems of higher productivity than in systems of lower productivity. Using a simple model with realistic values for bacterial and HNAN growth, respiration and mortality we have been able to recreate the numerical relationship observed between the 2 populations in nature. Based on an analysis of the model, a stronger control of bacterial abundance by grazers could be demonstrated in eutrophic ecosystems relative to oligotrophic ecosystems.

\section{METHODS}

A large part of the data set used in these analyses was obtained from the recent literature (Table 1). There were several requirements for including a study in our analyses: (1) the data to be compared (e.g. bacterial and HNAN abundances, bacterial productivity and bacterivoryj were collected concurrently within each study; (2) samples were from aerobic water within the euphotic zone $_{i}$ (3) data were not depth-integrated; (4) data were not from experimentally manipulated samples (e.g. microcosm experiments); and (5) HNAN were differentiated from autotrophic nanoplankton. An exception to the first requirement was the use of ranges of chlorophyll to predict the relative trophy of a system (Fig. 1). Our reasoning for excluding data that did not meet these minimum requirements was that the relationships between microbial populations and processes might be distorted.

Abundances of heterotrophic nanoplankton and bacteria were determined using fluorescent staining methods and epifluorescent microscopy in all cases. Estimates for bacterial production and grazing were obtained by a variety of methods. Other than converting to specific rates (i.e. $\mathrm{d}^{-1}$ ), no attempt was made to standardize these data for the different assumptions and methods. Least-squares regression analysis on log-transformed data was used to compare abundances of flagellates and bacteria in the different environments. The authors contributed some unpublished data on abundances of heterotrophic nanoplankton and bacteria contingent upon the criteria given above. A large data set that was recently published by one of the present authors (Berninger et al. 1991b) was not included in our analysis, but is compared in the 'Discussion' section.

A simple model was constructed using Stella (HighPerformance Systems) in order to explore factors which might affect the relationship between bacterial and HNAN abundances that are observed in natural 
Table 1. Sources of data used in Figs. 1 to 3

\begin{tabular}{|lll|}
\hline Abundances & Bacterial production and grazing & Chlorophyll \\
\hline Fresh waters & & Berninger (1990) \\
Bennett et al. (1990) & Nagata (1988) & Fahnenstiel et al. (1989) \\
Berninger (1990) & Riemann (1985) & Gray (1987) \\
Caron (1984) & Sanders \& Porter (1986) & Güde (1988) \\
Carrick \& Fahnenstiel (1989) & Sanders et al. (1989) & Pace (1982) \\
Güde (1986, 1988) & Scavia \& Laird (1987) & Simon (1987) \\
Sanders, unpublished & Servais et al. (1985) & \\
Scavia \& Laird (1987) & Tranvik (1989) & Andersen \& Sørensen (1986) \\
Tranvik (1989) & Weisse (1991) & Brown et al. (1985) \\
Marine and estuarine & & Caperon et al. (1979) \\
Caron (1984, unpubl.) & Coffin \& Sharp (1987) & Coffin \& Sharp (1987) \\
Caron et al. (1989) & Ducklow \& Hill (1985) & Cosper et al. (1989) \\
Coffin \& Sharp (1987) & Fuhrman \& McManus (1984) & Malone \& Ducklow (1990) \\
Davis et al. (1985) & Kuuppo-Leinikki (1990) & Roman et al. (1986) \\
Fenchel (1982b) & Landry et al. (1984) & B. F. Sherr et al. (1986) \\
Landry et al. (1984) & Servais et al. (1985) & Wright et al. (1987) \\
McManus \& Fuhrman (1988) & Taylor \& Pace (1987) & \\
McManus \& Peterson (1988) & Weisse (1989) & \\
Nielsen \& Richardson (1989) & Weisse \& Scheffel-Möser (1991) & \\
Sherr et al. (1984) & Wright \& Coffin (1984) & \\
Sieburth \& Davis (1982) & & \\
Weisse (1989) & & \\
Wright et al. (1987) & & \\
\end{tabular}

plankton samples. The approach was to mimic a trophic gradient (oligotrophic to eutrophic) by incrementally increasing substrate input rate in order to achieve steady state densities of bacteria and HNAN at each substrate level. For a given substrate level the input for bacterial growth was constant. The major biomass compartments of the model were bacteria, HNAN and HNAN-predators. Model output was in units of carbon and was converted to abundances using conversion factors of $10 \mathrm{fg} \mathrm{C}$ bacterium $^{-1}$ (Bratbak \& Dundas 1984) and $6500{\mathrm{fg} \mathrm{C} \mathrm{HNAN}^{-1}}^{-1}$ (Børsheim \& Bratbak 1987).

Losses from the bacterial and HNAN compartments were due to respiration and predation. Assumptions for calculating total respiration losses included a gross growth efficiency (GGE) of 0.5 for bacteria (Cole et al. 1982, Bjørnsen 1986) and 0.4 for HNAN (Caron \& Goldman 1990), and a maintenance (basal) respiration rate for bacterial and HNAN populations of $1 \% \mathrm{~d}^{-1}$ of their respective population biomass. Respiration losses thus were composed of 2 flows: respiration associated with growth that was calculated as a proportion $(1-G G E)$ of substrate uptake or feeding; and a maintenance respiration to support the current biomass. The low basal metabolic rate was chosen because by far the largest amount of energy use is directly coupled to growth and only a small fraction of the energy budget appears to be spent on mechanical or osmotic work (Fenchel 1982a, 1986).
Predation losses from the bacterial and HNAN compartments were based on density-dependent Michaelis-Menten (Monod) type relationships for HNAN grazing on bacteria and the removal of HNAN by their predators:

$$
\text { and } \begin{aligned}
\mathrm{d} B / \mathrm{d} t & =\left[a_{\mathrm{h}} B /\left(k_{\mathrm{b}}+B\right)\right] H_{1} \\
\mathrm{~d} H / \mathrm{d} t & =\left[a_{\mathrm{p}} H /\left(k_{\mathrm{h}}+H\right)\right] P,
\end{aligned}
$$

where $B, H$ and $P$ are the biomass of bacteria, HNAN, and HNAN-predators, respectively; $a_{h}$ and $a_{p}$ are the maximum specific predation rates per unit HNAN and HNAN-predator biomass, respectively; and $k_{b}$ and $k_{\mathrm{h}}$ are the half-saturation constants for removal of bacteria and HNAN. Lower grazing thresholds were created by setting predation losses to zero if the threshold abundance was reached. An upper limit to the biomass of the predators of HNAN $(P)$ was set to equal the biomass of HNAN.

The maximum grazing rate of the HNAN was 100 bacteria $\mathrm{HNAN}^{-1} \mathrm{~h}^{-1}$ (e.g. Berninger et al. 1991a), the threshold density of bacteria (density of bacteria below which HNAN grazing ceased) was $3 \times 10^{5}$ bacteria $\mathrm{ml}^{-1}$, and the half saturation constant (density of bacteria at which the HNAN grazing rate was half maximal, $k_{\mathrm{b}}$ ) was $6 \times 10^{5}$ bacteria $\mathrm{ml}^{-1}$. The half saturation constant was reduced ca $50 \%$ relative to that determined by Fenchel (1982a) for Pteridomonas danica on the assumption that HNAN in natural plankton would be adapted to feed at lower particle densities than those adapted to culture medium. Maximal removal rate of 


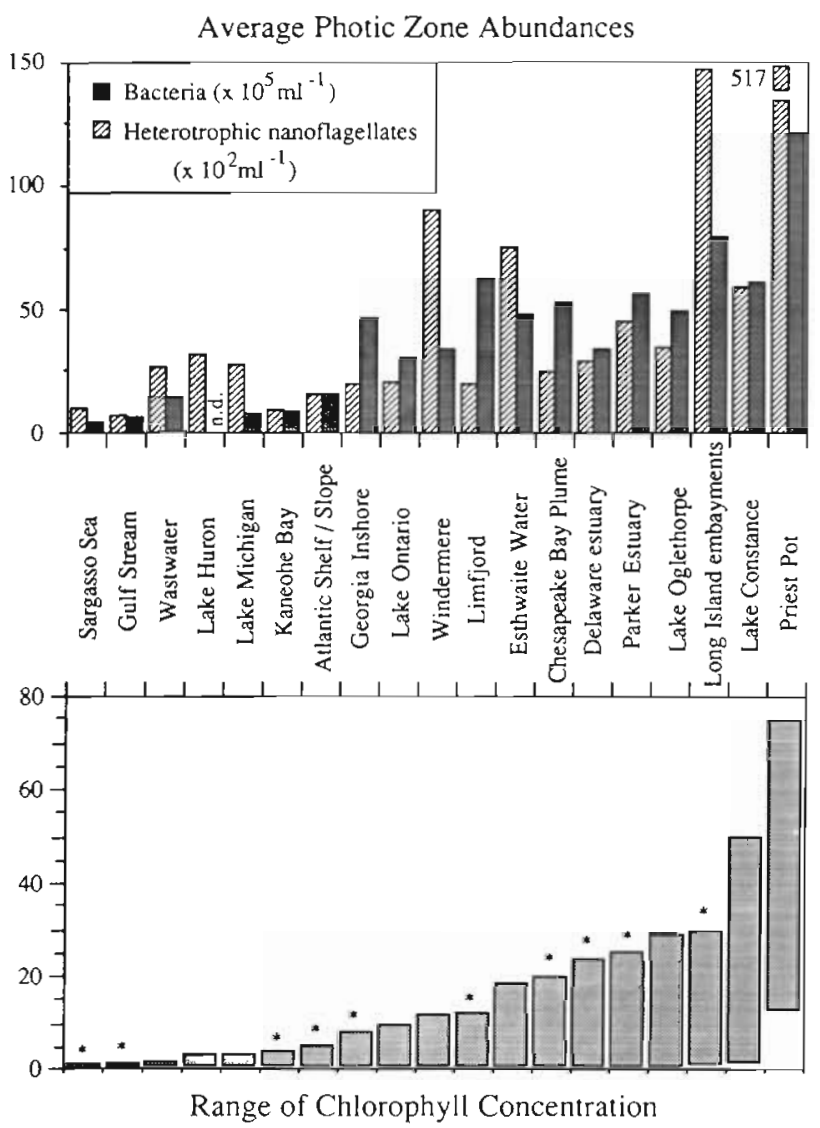

$\left(\mu \mathrm{g}^{-1}\right)$

Fig. 1. Average abundances of HNAN and bacteria in several freshwater and marine ecosystems arranged by increasing chlorophyll concentration. (*) Marine and estuarine environments

HNAN $\left[0.06 \mathrm{ng}\right.$ HNAN C (ng predator $\mathrm{C}^{-1} \mathrm{~h}^{-1}$ ] was based on the assumption that smaller grazers (i.e. rotifers, ciliates) would have a higher weight-specific ingestion rate of HNAN than that measured for crustaceans [0.04 ng prey $\mathrm{C}$ (ng predator $\mathrm{C}^{-1} \mathrm{~h}^{-1}$; Sanders unpubl.]. The threshold density ( $300 \mathrm{HNAN} \mathrm{ml}^{-1}$ ) was chosen because of the rarity of recorded HNAN abundances below $300 \mathrm{HNAN} \mathrm{ml}^{-1}$ (Berninger et al. 1991a). The half saturation constant $\left(k_{h}, 600 \mathrm{HNAN} \mathrm{ml}^{-1}\right)$ was arbitrarily chosen. We were able to reproduce stable equilibria of bacteria and HNAN using these conditions.

\section{RESULTS AND DISCUSSION}

\section{System trophy and microbial abundances}

Our purpose in this investigation was to examine the possible relationship between bacteria and their primary consumers across a range of aquatic ecosystems.
Previous studies have indicated that bacterial abundance increases with trophic state (Azam et al. 1983, Fuhrman et al. 1980) and that abundance and production of bacteria are positively correlated to chlorophyll a concentration (Bird \& Kalff 1984, Cole et al. 1988, White et al. 1991). A rigorous statistical analysis between the abundances and productivity of HNAN and system trophy was not possible because most of the studies that have reported abundances of HNAN did not include concurrent information on chlorophyll concentration or primary production. Moreover, very few estimates of HNAN production have been made. A comparison of the available data on the average abundances of HNAN in the euphotic zone to ranges of chlorophyll in several freshwater and marine ecosystems, however, indicated a positive relationship between these parameters that was independent of salinity (Fig. 1). This trend is similar to the relationship between average abundances of bacteria and chiorophyll concentrations in these same environments (Fig. 1). As stated previously, a strong correlation between bacterial abundances and chlorophyll concentrations has been observed with much larger data sets (Cole et al. 1988, White et al. 1991).

A more rigorous analysis of correlation between populations of heterotrophic microorganisms was performed by comparing data sets containing concurrently collected measurements of bacterial and HNAN abundances (Fig. 2). Abundances of HNAN in this data set typically ranged from ca $10^{2}$ to $10^{4} \mathrm{ml}^{-1}$ in both marine and freshwater planktonic communities (Fig. 2, Table 2), but occasionally exceeded $10^{5} \mathrm{ml}^{-1}$ in ex-

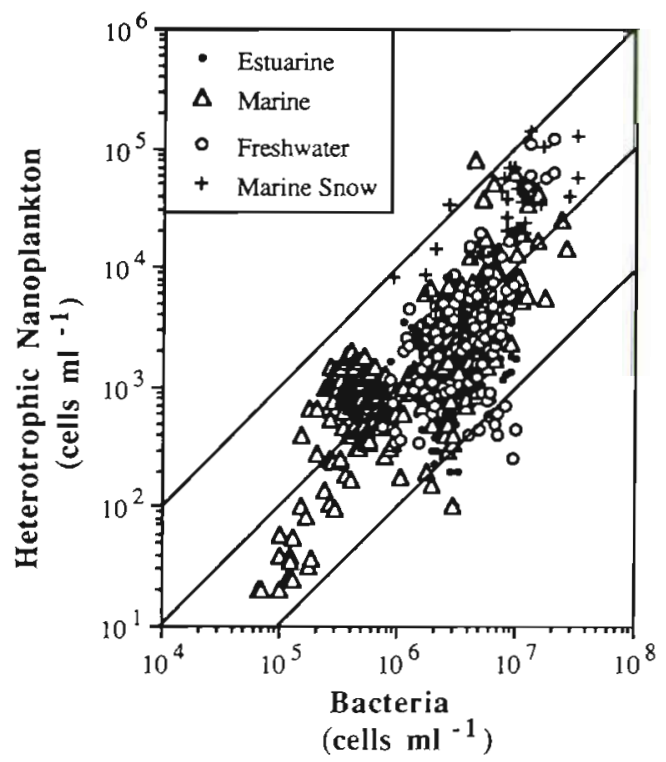

Fig. 2. Bacterial abundance vs HNAN abundance for 600 samples from a variety of planktonic ecosystems. Lines represent ratios of $10^{2} \cdot 1,10^{3}: 1$ and $10^{4}: 1$ bacteria:HNAN 
Table 2. Minimum and maximum abundances and the coefficients of variation (CV) (when available) of bacteria and heterotrophic nanoplankton observed during different seasons in a variety of planktonic environments

\begin{tabular}{|c|c|c|c|c|c|c|c|c|}
\hline \multirow[t]{2}{*}{ Environment } & \multicolumn{3}{|c|}{$\begin{array}{l}\text { Flagellates } \\
\left(\times 10^{3} \mathrm{ml}^{-1}\right)\end{array}$} & \multicolumn{3}{|c|}{$\begin{array}{c}\text { Bacteria } \\
\left(\times 10^{6} \mathrm{ml}^{-1}\right)\end{array}$} & \multirow[t]{2}{*}{$\mathrm{n}$} & \multirow[t]{2}{*}{ Source } \\
\hline & Min. & Max. & CV & Min. & Max. & $\mathrm{CV}$ & & \\
\hline \multicolumn{9}{|l|}{ Freshwater } \\
\hline Esthwaite Water, UK & 3.8 & 23.0 & 48 & 3.6 & 12.0 & 32 & 7 & Berninger (1990) \\
\hline Lake Biwa, Japan & 0.8 & 5.1 & & & & & & Nagata (1988) \\
\hline Lake Constance, Germany & 0.5 & 8.1 & 90 & 0.4 & 11.7 & 29 & 17 & $\begin{array}{l}\text { Güde }(1988) \\
\text { Weisse }(1990)\end{array}$ \\
\hline Lake Huron, N. America & 1.0 & 5.0 & 49 & - & - & - & 12 & Carrick \& Fahnenstiel (1989) \\
\hline Lake Klintsjön, Sweden & 1.8 & 3.6 & 24 & 2.1 & 3.0 & 15 & 5 & Tranvik (1989) \\
\hline Lake Michigan, USA & 1.1 & 9.0 & - & - & - & - & 16 & Carrick \& Fahnenstiel (1989) \\
\hline Lake Oglethorpe, USA & 0.9 & 15.0 & 85 & 2.3 & 16.8 & 34 & 23 & $\begin{array}{l}\text { Sanders \& Porter (1986), } \\
\text { Bennett et al. (1990) }\end{array}$ \\
\hline Lake Ontario, N. America & 0.8 & 4.6 & 66 & 1.7 & 6.1 & 47 & 20 & Caron (1984) \\
\hline Lake Skärshutsjön, Sweden & 1.8 & 5.4 & 45 & 4.2 & 7.2 & 8 & 5 & Tranvik (1989) \\
\hline Pond, Georgia, USA & 0.9 & 7.4 & - & 7.6 & 17.0 & - & & Carlough \& Meyer (1990) \\
\hline Priest Pot, UK & 13.0 & 180.0 & 81 & 5.2 & 34.0 & 51 & 9 & Berninger $(1990)$ \\
\hline Upton Lake, NY, USA & 0.4 & 1.3 & - & 1.8 & 10.0 & - & & Pace et al. (1990) \\
\hline Wastwater, UK & 1.1 & 13.0 & 40 & 1.1 & 1.8 & 14 & 7 & Berninger (1990) \\
\hline Windermere, UK & 1.8 & 19.0 & 66 & 2.1 & 5.5 & 39 & 8 & Berninger (1990) \\
\hline \multicolumn{9}{|l|}{ Marine and estuarine } \\
\hline Delaware Estuary, USA & 0.4 & 9.0 & 70 & 1.0 & 8.0 & 39 & 85 & Coffin \& Sharp (1987) \\
\hline Limfjord, Denmark & 0.2 & 15.2 & - & 0.5 & 15.2 & - & & Andersen \& Sorensen (1986) \\
\hline Limfjord, Denmark & 0.1 & 4.2 & 77 & 1.3 & 3.4 & 24 & 84 & Fenchel (1982b) \\
\hline Parker Estuary, Mass., USA & 0.3 & 21.9 & - & 0.9 & 14.6 & - & & Wright et al. (1987) \\
\hline Chesapeake Plume, USA & 0.8 & 4.4 & 64 & 1.1 & 9.1 & 48 & 16 & McManus \& Fuhrman (1988) \\
\hline Georgia Coast, USA & 0.3 & 3.2 & 77 & 2.0 & 11.0 & 53 & 28 & Sherr et al. (1984) \\
\hline Atlantic Shelf, USA & 0.4 & 3.2 & 58 & 0.7 & 2.2 & 33 & 13 & Caron (1984) \\
\hline Gulf Stream & 0.3 & 1.6 & 55 & 0.2 & 1.5 & 53 & 19 & Caron (1984) \\
\hline Sargasso Sea & 0.2 & 1.1 & 45 & 0.2 & 0.9 & 40 & 49 & Caron (1984) \\
\hline Red Sea/Gulf of Aden & 0.6 & 1.2 & 21 & 0.5 & 0.9 & 16 & 17 & Weisse (1989) \\
\hline North Sea & $<0.1$ & 6.6 & 224 & 0.1 & 2.7 & 125 & 25 & Nielsen \& Richardson (1989) \\
\hline Marine snow, N. Atlantic & 1.3 & 182.0 & 94 & 0.9 & 250.0 & 222 & 41 & Caron (1984) \\
\hline
\end{tabular}

tremely eutrophic waters and on marine snow particles (macroscopic detrital aggregates). Bacterial abundances ranged over approximately 3 orders of magnitude from $10^{5}$ to $10^{8} \mathrm{ml}^{-1}$. Log-transformed abundances of HNAN and bacteria were significantly correlated $\left(\mathrm{r}^{2}=0.50, \mathrm{p}<0.001, \mathrm{n}=600\right)$ using the relationship:

Log HNAN abundance =

0.90 Log bacteria abundance - 2.4

The middle line in Fig. 2 represents a bacteria:HNAN ratio of 1000:1 which has been reported as a generalization for marine plankton (Fenchel 1986). The average ratio calculated at the mean of the regression for the whole data set included in our analysis was 1133 bacteria $\mathrm{HNAN}^{-1}$.

The significance level was unchanged when the regressions for the marine, estuarine and freshwater data sets were considered separately, and there were no significant differences between the slopes of the log-transformed data from oceanic, estuarine and fresh waters (ANCOVA). More data were available for HNAN and bacterial abundances from marine and estuarine ecosystems than from freshwater ecosystems. Consequently, regressions were based on approximately twice as many data points from oceanic ecosystems. The relationship calculated for all ecosystems in our study was consistent with the regression of freshwater HNAN and picoplankton reported in a previous analysis (slope $=1.12, y$-intercept $=3.52$, $\mathrm{r}^{2}=0.82$; Berninger et al. 1991a). We excluded the data from Berninger et al. (1991a) from the current analysis to avoid biasing the results with this single large data set.

Neither absolute nor average photic zone abundances of microorganisms offered a predictable relationship which differentiated between the marine and freshwater data (Figs. 1 \& 2, Table 2). Bacterial and HNAN abundances in freshwater and marine samples strongly overlapped over most of the range of the oligotrophic-eutrophic continuum. The lowest abun- 
dances of microorganisms, however, were observed in samples from pelagic marine systems. Highest abundances were observed in marine snow samples which can be regarded as highly eutrophic microzones in aquatic environments (Caron et al. 1982, 1986), and in freshwater ecosystems where allochthonous inputs probably contributed to bacterial productivity

\section{Bacterial growth versus bacterial removal}

There was considerable variability associated with the correlation between HNAN abundance and bacterial abundance (Fig, 2). A discussion of this variability will be provided later. Given the number of factors that might affect this relationship, however, it is remarkable that such a strong correlation persists across a wide spectrum of freshwater and marine ecosystems. What conditions might explain why both bacterial and HNAN abundances increase along a trophic gradient? The timing and magnitude of bacterial production and bacterial grazing probably are the key to understanding this phenomenon. Production and grazing in phytoplankton-zooplankton communities have been modeled as balancing processes that equilibrate at different levels of abundance along an oligotrophiceutrophic gradient (Leibold 1989).

A comparison of the available data on bacterial production and grazing indicated that, on average, there is a strong 1:1 correspondence between these 2 parameters (Fig. 3). The overall relationships were similar to those reported by McManus \& Fuhrman (1988) and Sanders et al. (1989) using smaller data sets. The best fit $\left(r^{2}=0.59\right)$ of the least-squares regression for the data set presented here is:

$$
G R Z=0.84 P R O D+0.17
$$

where $G R Z$ and $P R O D$ are specific rates of grazing mortality and bacterial growth respectively.

In a stable community (i.e. where bacterial abundance is not changing), equivalent amounts of bacterial production and grazing are expected if grazing is the primary source of bacterial mortality. Interannual abundances of bacteria are relatively stable in most environments because bacterial cells produced are ultimately removed by grazing. It is not necessary (nor probable), however, for these processes to occur at the same rate at all times. If changes in bacterial production (increases or decreases) occur concomitantly with equivalent changes in grazing, then the bacterial density does not change. If the bacterial production and grazing rates do not match, however, bacterial abundances will increase or decrease depending on the relative magnitude of the 2 rates.

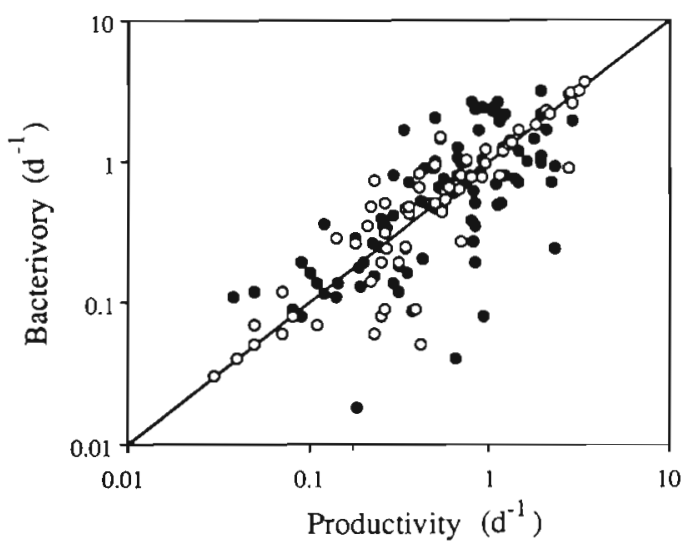

Fig. 3. Relationship of specific community bacterivory $\left(\mathrm{d}^{-1}\right)$ to bacterial productivity $\left(\mathrm{d}^{-1}\right)$ in $(0)$ freshwater and $(\bullet)$ marine ecosystems. The line represents a balance $(1: 1$ correspondence) between production and grazing. Modified from Sanders et al. (1989) with additional data

These situations are represented conceptually in Fig. 4. The double-headed arrow (1) in Fig. 4A depicts the condition in which changes in bacterial production and grazing are matched in magnitude and timing. Regardless of the starting bacterial density, changes in
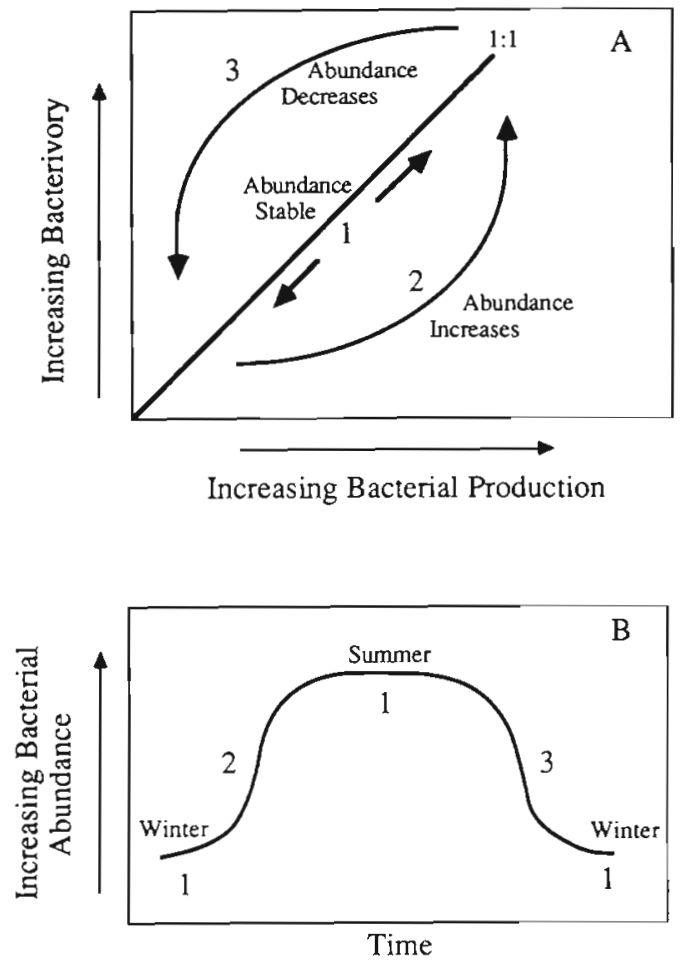

Fig. 4. A conceptual model of $(A)$ bacterial production and grazing losses and $(B)$ the resulting changes in abundances. The 1:1 line in (A) represents periods when bacterial production and death are balanced. The numbers in (A) correspond to those in (B). See text for discussion 
the bacterial production rate do not affect the abundance of bacteria as long as changes in the grazing rate equal changes in the production rate. Bacterial production and grazing, however, frequently do not balance (arrows 2 and 3 in Fig. 4A, scatter in Fig. 3). If an increase in bacterial production is not immediately matched by an equivalent increase in grazing (arrow 2 in Fig. 4A) then bacterial abundance increases until a new, higher equilibrium between production and grazing is reached (i.e. when arrow 2 in Fig. $4 \mathrm{~A}$ reaches the line of 1:1 correspondence). At that point, bacterial losses again equal bacterial production and the bacterial abundance will stabilize at this higher density. On the other hand, if a decrease in bacterial production is not immediately matched by an equivalent decrease in grazing (arrow 3 in Fig. 4A), then the bacterial abundance decreases until a new, lower equilibrium between production and grazing is reached (i.e. when arrow 3 reaches the line of $1: 1$ correspondence).

Note that the location along the $1: 1$ correspondence line of Fig. 4A does not stipulate the density of the bacterial population, but merely a balance between the rates of bacterial production and grazing. It is possible that either low or high stable bacterial densities could be maintained in an environment if bacterial production and grazing are equal. An example would appear to be winter-summer abundances of bacteria in most temperate aquatic environments. Summer abundances of bacteria in surface waters of these environments typically are approximately 1 order of magnitude higher than winter abundances, but both densities are relatively stable over periods of several months (e.g. Berninger et al. 1991b). The probable sequence of events explaining this situation would begin with a substrate- and/or temperature-related increase in bacterial production during the spring prior to an increase in grazing pressure (arrow 2 in Fig. 4A \& B). Bacterial density increases until the production and grazing rates become equal (i.e. reach the line of 1:1 correspondence), and then remains stable at this higher density as long as these 2 rates remain approximately equal (Fig. 4B). As temperature and/or substrate supply decrease in the autumn, bacterial production decreases more rapidly than grazing (arrow 3 in Fig. 4A \& B). Bacterial abundance also decreases until the production and grazing rates again become equal (i.e. reach the line of 1:1 correspondence).

The simple example described above assumes that a stable bacterial abundance is achieved during the summer and again during the winter. The model depicted in Fig. 4A, however, can also be used to explain short-term changes in bacterial abundance due to predator-prey oscillations. An increase in bacterial abundance resulting from the bacterial production rate exceeding the grazing rate (arrow 2 in Fig. 4A) is followed by a rapid decrease in bacterial abundance resulting from the bacterial grazing rate exceeding the production rate (arrow 3 in Fig. 4A). In this situation, however, the lines depicting the production:grazing ratio on Fig. $4 \mathrm{~A}$ (arrows 2 and 3) tend to transect the line of 1:1 correspondence (arrow 1) resulting in very short-lived equilibrial abundances of bacteria. These predator-prey induced oscillations in bacterial and HNAN abundances in nature can result in significant day-to-day variations in the densities of these microorganisms (Fig. 5) but these variations generally are not of the same magnitude as seasonal changes in their abundances. Whereas seasonal changes in abundance in nature can be an order of magnitude or more, changes in abundance that are due to predator-prey oscillations typically are no more than a factor of 2 to 3 (Fig. 5). The oscillations in the abundances of bacteria and HNAN derived from enumeration of natural samples (Fig. 5) must, however, be interpreted with some caution. Other factors including alternative food sources and predators, and sampling and methodological inaccuracies can contribute to these short term variations of the microorganism abundances.
Fig. 5. Short-term oscillations of bacteria and HNAN during the stratified period (June to September) in Priest Pot, a hyper-eutrophic pond (Berninger 1990)

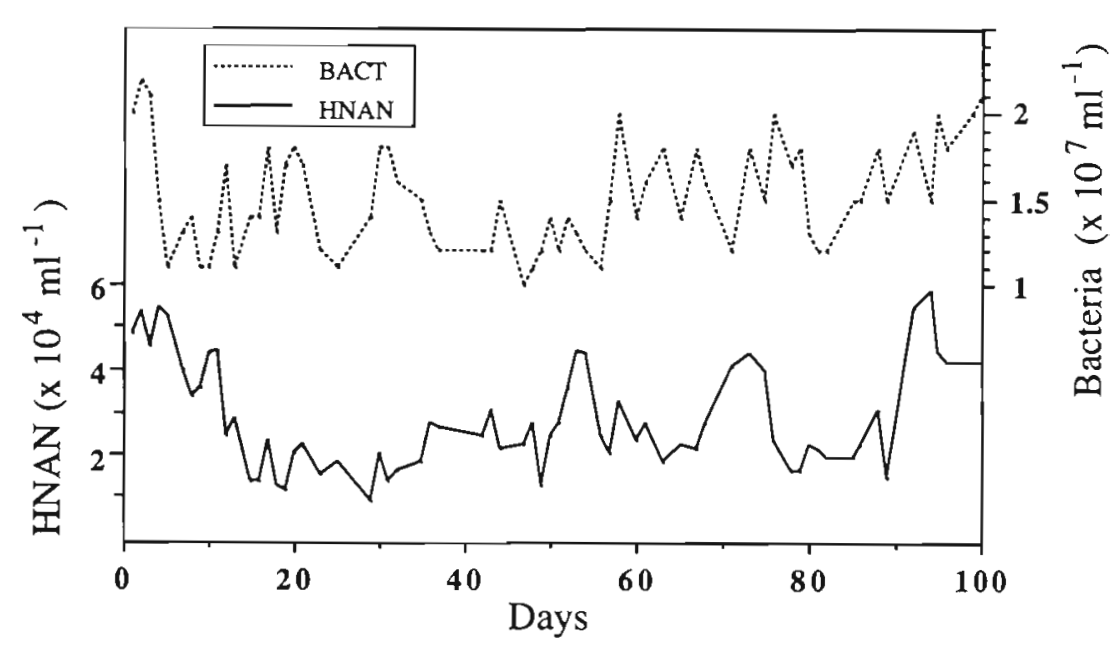




\section{Modeling in situ bacterial and HNAN abundances}

The simple model presented in Fig. 4 provides a conceptual framework for understanding the existence of relatively stable abundances (as well as oscillations) of bacteria in nature. To examine the correlation that exists between abundances of bacteria and their consumers, the HNAN, observed across ecosystems and depicted in Fig. 2, we developed a model simulating a substrate-bacteria-HNAN food chain. Our specific goals in this work were (1) to simulate realistic conditions that would generate the abundances of bacteria and HNAN that co-occur in natural aquatic communities and (2) to examine the relative importance of grazing as a factor controlling bacterial density along an oligotrophic-eutrophic gradient.

We initiated the model with a low rate of substrate supply for bacterial growth and chose realistic grazing parameters for the model (HNAN grazing on bacteria and larger organisms grazing on HNAN). The model was run until steady state densities of bacteria and HNAN were obtained such that the bacteria:HNAN ratio was ca 1000:1. We adjusted the model to this ratio because it represents a rough approximation of the bacteria:HNAN ratio in nature (Fig. 2; Fenchel 1986). We then incrementally increased the rate of substrate supply for bacterial growth to simulate an oligotrophic-eutrophic gradient with steady state densities of bacteria and HNAN established at each new input rate. We observed that, with a constant density-dependent grazing rate on the HNAN, the bacteria:HNAN ratio increased as the rate of substrate input was increased (Fig. 6). In order to maintain the

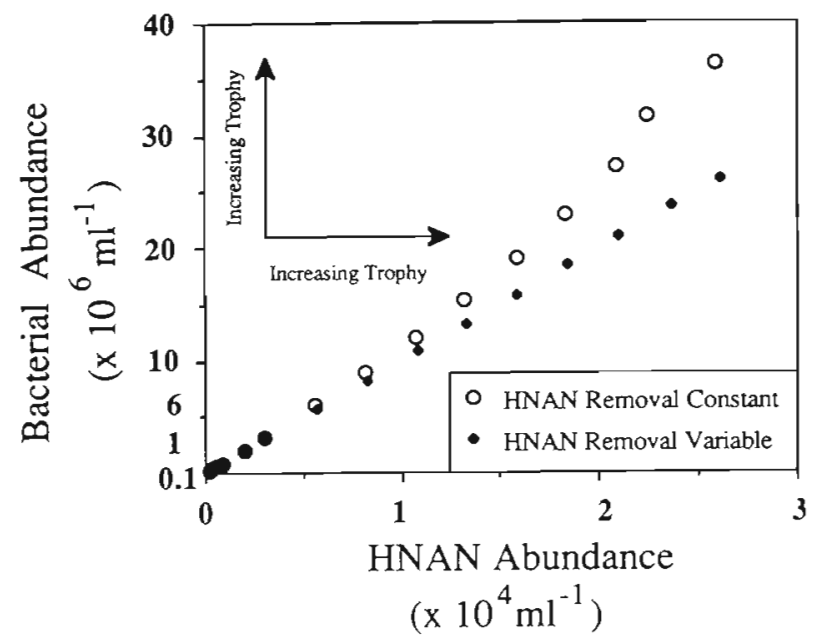

Fig. 6. Bacterial abundances vs HNAN abundances predicted from a simple model, over a range of substrate input rates, with (0) a constant removal rate of HNAN and ( $\downarrow$ ) a variable removal rate such that the bacteria:HNAN ratio remains constant at 1000:1
1000:1 ratio observed in nature, it was necessary to reduce the grazing pressure on the HNAN assemblage at the higher substrate levels, thereby increasing their abundance and the amount of bacterivory by HNAN. This in turn reduced the abundance of bacteria relative to HNAN at the higher substrate levels and maintained the 1000: 1 ratio (Fig, 6). From this result, we concluded that grazing pressure by HNAN on the bacterial assemblage must be proportionally greater in eutrophic than in oligotrophic environments in order to maintain a constant bacteria:HNAN ratio of 1000:1.

This result implies that, in eutrophic environments, HNAN grazing exerts a stronger control over bacterial abundances than in oligotrophic environments. The other major loss factor to the HNAN compartment in the model was respiration, and the 1000:1 ratio could also be maintained in the model by increasing the HNAN respiration rate as food resources increased (i.e. decreasing GGE in more eutrophic environments). Maintaining a constant gross growth efficiency throughout the range of substrate input and increasing the grazing pressure on HNAN was the more appropriate manipulation, however, because GGE (cell yield) does not appear to change significantly with growth rate (food resource input) for bacteria or protozoa (Fenchel 1982a).

Another way of examining the possibility that grazing by HNAN must be proportionally greater in eutrophic environments is to consider the 'carrying capacity' of an environment for the bacterial assemblage in the absence of mortality (i.e. when only bacterial maintenance metabolism is responsible for the loss of bacterial biomass). In order to investigate this possibility we reran the model with the original rates of maintenance and growth respiration, but removed all grazing pressure on the bacterial assemblage thereby generating new steady state densities. We then calculated the ratio between the bacterial 'carrying capacity' determined in this way and the bacterial abundance at the same rate of substrate supply but with grazing losses. We repeated the process of determining the ratio of these abundances along an oligotrophic-eutrophic gradient. We observed that the 'carrying capacity' of the environment for bacteria relative to the bacterial abundance in the presence of bacterivory (CC:BAB) increased as the rate of substrate input increased (Fig. 7). The increase in carrying capacity with increasing eutrophication is, of course, dependent on the assumption that the rate of bacterial basal metabolism remains constant per unit biomass across the range of substrate concentrations. The validity of this assumption is indirectly supported by the observation that natural waters with high organic content support a higher biomass of bacteria in the absence of grazing (i.e. have a higher carrying capacity) 


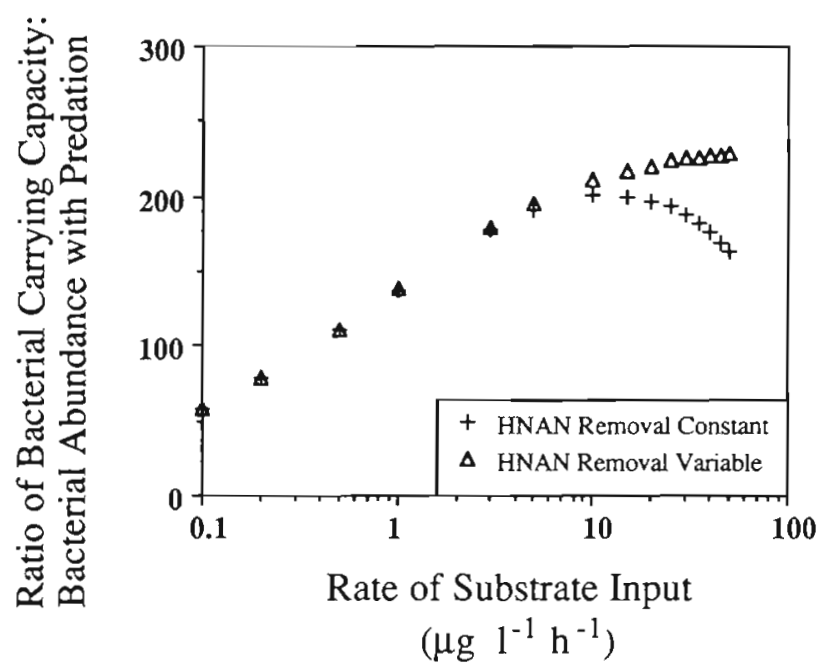

Fig. 7 Ratio of the bacterial carrying capacities of systems in the absence of bacterivory to the steady state bacterial abundances with grazing present, predicted from a simple model. $(+)$ : predictions over a range of substrate input rates when grazing on HNAN is constant; $(\Delta)$ : predictions when grazing on HNAN is varied to keep the bacteria:HNAN ratio constant at 1000:1

than waters lower in dissolved organics (Tranvik 1988, Sanders unpubl.). For the model iterations with constant density-dependent HNAN grazing, the ratio of $\mathrm{CC}: \mathrm{BAB}$ increased from 59 to 200 (factor of 3.4) over the range of substrate supply rates of 0.1 to $10 \mu \mathrm{g}$ $\mathrm{C}^{-1} \mathrm{~h}^{-1}$ and then decreased slightly at higher supply rates (Fig. 7). When the grazing pressure on the HNAN assemblage was reduced in order to maintain the 1000:1 bacteria:HNAN ratio, the decrease at higher substrate supply rates did not occur, and the ratio of bacterial abundances with and without grazing continued to increase slightly (up to 228) over the entire range of substrate supply rates examined (Fig. 7).

Fenchel (1986) suggested that grazing by heterotrophic nanoplankton maintained bacteria just below their carrying capacity in oligotrophic ecosystems, but in eutrophic ecosystems the mean number of bacteria were kept well below the carrying capacity by HNAN grazing. The results of our modeling with constant density-dependent HNAN grazing on bacteria (Fig. 6) were consistent with this suggestion that bottom-up control was more important in regulating bacterial abundances in oligotrophic environments and that topdown control was more important in eutrophic environments (Fenchel 1986). This conclusion is supported by the increase from 1000:1 of the bacteria:HNAN ratio in Fig. 6. The comparison of steady state densities of bacteria in the presence or absence of bacterivory along an oligotrophic-eutrophic gradient (Fig. 7), further indicated strong grazer control of bacterial abundance in eutrophic environments.
The range of the ratios of bacteria: HNAN observed in nature from ecosystems of different productivities (Fig. 8) also indicates that top-down control may be more important in eutrophic than in oligotrophic environments. Low bacteria: HNAN ratios occurred across all environments but high ratios of bacteria:HNAN occurred only in relatively eutrophic ecosystems. The range of the ratios, therefore, was much greater in eutrophic ecosystems because of occasionally high values in these environments (Fig. 8). Once again this trend appeared to be independent of salinity. The increasing variability in the ratio with increasing eutrophication also is reflected by the coefficients of variation (Fig. 8). If top-down control is more important in eutrophic ecosystems then we would expect that these environments possess the potential for much greater ratios than 1000:1 in those instances where grazer control of bacterial abundance becomes temporarily uncoupled. Oligotrophic ecosystems, on the other hand, would not be expected to show large increases from the 1000:1 ratio because the bacterial population is more strongly controlled by substrate supply (i.e. even in situations when grazing pressure on bacteria is reduced, the bacteria are not capable of rapid increases in abundance because of substrate limitation).

In contrast to our analyses, a modeling approach recently was used to argue that there is little top-down control of bacterial biomass at any level of enrichment (Billen et al. 1990). They found that the bacterial biomass was dependent on system richness (i.e. substrate input) when the bacterial mortality constant of their model was a function only of bacterial biomass (Billen et al. 1990). Thus, their model prediction fit the empirical data in both their paper and ours. When a

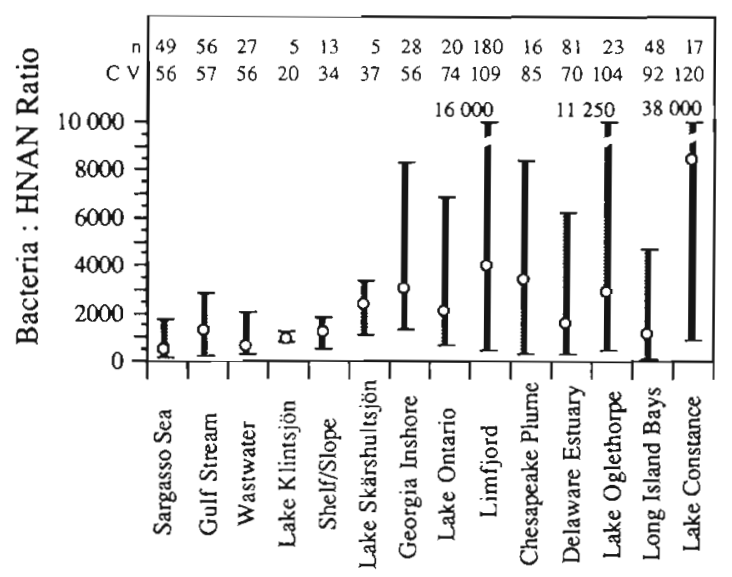

Fig. 8. Averages and ranges of the ratio of bacteria to HNAN in a variety of planktonic ecosystems. The environments are listed in order of increasing chlorophyll concentration as in Fig. 1. Number of samples (n) and coefficients of variations $(\mathrm{CV})$ are listed above the ranges 
predator-dependent bacterial mortality was added to their model, however, bacterial biomass became independent of system richness. From their work it was concluded that grazing was not of primary importance in the control of bacterial biomass (Billen et al. 1990). Interestingly, our model with predator-dependent mortality predicted, as did the Billen et al. (1990) model without grazing, that bacterial abundance would increase with increasing substrate input. We suggest therefore that differences in the abundance of bacteria between oligotrophic and eutrophic environments should be modeled without discarding grazing as an important controlling factor. The differences between these models are a function of their structures, and are likely due to the choices for constants (halfsaturation constant and maximum rate of uptake) and 'closure' by the grazing function (Steele \& Henderson 1992). The importance of the mortality closure to food web models is reflected by the differences in the ratios of bacteria:HNAN when we change the constant HNAN mortality to variable mortality (Figs. 6 \& 7).

\section{Trophic relationships and the cascade effect}

Using realistic starting conditions, we developed a model that reflected published results on bacterial and HNAN abundances across an oligotrophic-eutrophic gradient in natural ecosystems. The trend for greater abundances of bacteria and HNAN in more eutrophic environments (Fig. 1) was predicted (Fig. 6), and the results of the model (Figs. $6 \& 7$ ) were consistent with data (Fig. 8) that indicated an increasing importance of bacterivory along a gradient of increasing substrate supply. The sensitivity of the bacteria:HNAN ratio to changes in the HNAN grazing pressure (Figs. 6 \& 7) implies an important role for a 'trophic cascade' for controlling the numerical relationship between HNAN and bacteria in the microbial loop. Ratios of bacteria:HNAN close to 1000:1 were obtained for high rates of substrate input when predation on HNAN by higher organisms was reduced (Fig. 6). The reduction of grazing by higher organisms on HNAN resulted in higher HNAN densities and consequently a cascade effect increasing the grazing pressure of HNAN on bacteria. The effect of this trophic cascade acted to decrease the steady state bacterial abundance and the bacteria:HNAN ratio to ca 1000: 1.

Based on the discussion in the previous paragraph, we speculate that the high ratios of bacteria: HNAN in eutrophic ecosystems (Fig. 8) are a consequence of intense predation of larger organisms on HNAN. The removal of HNAN biomass by predators results in reduced HNAN grazing on the bacteria. Presumed high rates of substrate supply in eutrophic ecosystems coupled with reduced removal rates allow rapid bacterial growth and, occasionally, high bacteria:HNAN ratios. Cascading trophic effects as described above have been reported from freshwater fish-zooplanktonphytoplankton communities (McQueen et al. 1989). There are still few data for microbial communities, but such trophic cascade effects have been implicated in the microbial food webs of Lake Constance (Güde 1988) and the Rhode River (Dolan \& Gallegos 1991). Ciliates, rotifers, cladocera and other crustacean zooplankton are all potentially important sources of predation on HNAN

It should be noted that data contrary to the trophic cascade concept in microbial communities also has been reported (Pace \& Funke 1991). Protozoan removal by crustacean zooplankton in that study was not followed by a rapid increase in bacterial abundance. One possible explanation for these results that would remain consistent with the results of our work include a switch from HNAN-dominated bacterivory to bacterivory by other zooplankton at the time of the reduction of protozoan abundance. Alternatively, if a system were oligotrophic, a rapid increase in bacterial abundance would not be expected because the bacterial population would be near substrate limitation. Interestingly, the ecosystems examined by Pace \& Funke (1991) were relatively oligotrophic in which case our model would not predict a strong response of the bacterial assemblage to removal of predators. Clearly, these possible explanations warrant further study.

\section{Caveats}

The correlation of bacteria and HNAN abundances that we observed (Fig. 2) has not always been noted in field data (Wright et al. 1987, McManus \& Fuhrman 1990). A lack of correlation certainly might result when examining smaller data sets or data sets confined to particular environments. The most important of several confounding influences may be the occurrence of predator-prey oscillations. These oscillations may result in short-term disequilibria between the bacterial and HNAN abundances. Seasonal changes in abundances may also contribute to deviations from the correlation observed in Fig 2. These factors undoubtedly account for much of the scatter in the data of Fig. 2.

Two other crucial factors that may cause deviations from the correlation in Fig. 2 are trophic coupling of HNAN with higher organisms (i.e. the trophic cascade) and bacterivory by organisms other than HNAN. We have previously demonstrated the potential importance of a trophic cascade on the relationships between bacterial and HNAN abundances (Figs. 6 \& 7; Güde 1988, Dolan \& Gallegos 1991). Likewise, the importance 
of bacterivores other than HNAN, including mixotrophic flagellates, ciliates, cladocera and rotifers has been noted in a number of studies (Bird \& Kalff 1986 , Sherr et al. 1986, Sanders et al. 1989, Pace \& Funke 1991). The utilization by HNAN of alternative prey, such as photosynthetic picoplankton or nanoplankton (Caron et al. 1991), also may introduce variability in the relationship between HNAN and bacteria.

These considerations may obliterate the correlation noted in Fig. 2 in some environments. For example, in benthic environments ciliates may be important consumers of bacteria. Under such circumstances, a correlation between the abundances of bacteria and bacterivorous flagellates would not be expected. Osmotrophic nutrition of flagellates in enriched benthic environments may further obscure any numerical relationship between bacteria and flagellates. Finally, attachment to suspended particles may give bacteria a refuge from grazing and confuse the interpretation of the bacterial and HNAN relationships in the plankton.

Two studies have presented data on the numerical relationship between bacteria and HNAN that do not conform to our model and our summary of field data spanning a range of environments from oligotrophic to eutrophic. Davis et al. (1985) observed a trend of decreasing bacteria:HNAN ratios along an oligotrophic-eutrophic (offshore-nearshore) gradient in the North Atlantic ocean. A significant decrease in the ratio of bacteria:HNAN with increasing chlorophyll also was found in an outflow plume of the Chesapeake Bay (McManus \& Fuhrman 1990). These trends are contrary to the results of our model (Figs. $6 \& 7$ ), our compilation of bacteria:HNAN ratios (Fig. 8), and to the conclusions of Fenchel (1986). We speculate that the use of a limited data set by Davis et al. (1985), and the limited geographic range of the McManus \& Fuhrman (1990) study, may explain why their data differ from our own.

\section{Constraints on microbial abundances and production}

Assuming that the data set used in this paper is representative of planktonic ecosystems, we are able to place some constraints on removal of bacteria by grazers and on the production of bacteria and bacterivorous HNAN. In oligotrophic waters, the ratio of bacteria:HNAN typically ranges from 400 to 1000 . If HNAN removed all the bacterial production, ingestion rates would need to be 17 to 42 bacteria $\mathrm{HNAN}^{-1} \mathrm{~h}^{-1}$ to balance a bacterial division rate of $1.0 \mathrm{~d}^{-1}$. Because measured bacterivory in oligotrophic systems has been reported to be in the range of 10 to 35 bacteria $\mathrm{HNAN}^{-1} \mathrm{~h}^{-1}$ (Weisse \& Scheffel-Möser 1991), bacterivorous nanoplankton could easily maintain the observed ratio of bacteria:
HNAN at bacterial growth rates of $1.0 \mathrm{~d}^{-1}$. Assuming microbial abundances of $5 \times 10^{5} \mathrm{ml}^{-1}$ (bacteria) and $500 \mathrm{ml}^{-1}$ (HNAN), and a relatively low grazing rate of 10 bacteria $\mathrm{HNAN}^{-1} \mathrm{~h}^{-1}$, HNAN alone could turn over the total bacterial population in $4.2 \mathrm{~d}$. Using HNAN abundance and bacterial cell production data from the Sargasso Sea during July 1988 (Fuhrman et al. 1989), flagellates would need to ingest only 10 to 18 bacteria $\mathrm{h}^{-1}$ to balance production. These ingestion rates are well within the range of ingestion rates measured for heterotrophic nanoplankton.

Limits can also be placed on the production of HNAN. If bacteria were the only food of HNAN in oligotrophic waters, doubling times of $\leq 1 \mathrm{~d}$ would be realistic. For example, during the summer in the Sargasso Sea, bacterial production of $4.8 \mathrm{ng} \mathrm{C} \mathrm{mil}^{-1} \mathrm{~d}^{-1}$ is not unusual (Fuhrman et al. 1989). If HNAN consumed all bacterial production with a growth gross efficiency of $40 \%$, then $1.9 \mathrm{ng} \mathrm{C} \mathrm{ml} \mathrm{Cl}^{-1} \mathrm{~d}^{-1}$ would be converted to HNAN biomass. Depending on the size of the HNAN ( 2.5 to $4 \mu \mathrm{m}$ diameter), this would be equivalent to the production of 500 to 900 HNAN $\mathrm{ml}^{-1} \mathrm{~d}^{-1}$. If a significant biomass of cyanobacteria was also ingested (e.g. Hagström et al. 1988, Caron et al. 1991), then a doubling time of $<24$ h certainly would be possible. HNAN population growth would be lower of course if bacterial and/or cyanobacterial removal rates were due to other factors such as viral infection or other grazers such as ciliates, mixotrophic algae and appendicularia.

Using the same assumptions for a eutrophic environment (Lake Oglethorpe) where bacterial production may be on the order of $2 \times 10^{6}$ cells $\mathrm{ml}^{-1} \mathrm{~d}^{-1}$ (41 $\mathrm{ng} \mathrm{C}$ $\mathrm{ml}^{-1} \mathrm{~d}^{-1}$ ) and HNAN abundances about $2 \times 10^{3}$ cells $\mathrm{ml}^{-1}$ (Sanders et al. 1989), HNAN would need to ingest

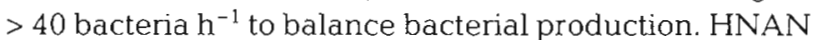
ingestion rates as high as this have been measured in situ. Given the same assumptions used above for oligotrophic systems, population growth of HNAN in the absence of predation could range from 4.8 to $7.8 \times 10^{3}$ HNAN ml ${ }^{-1} \mathrm{~d}^{-1}$. HNAN biomass production in this range has been calculated for both coastal marine waters and mesotrophic lakes (Sherr et al. 1984, Nagata 1988, Weisse 1991). This HNAN biomass could easily be removed completely by cladocera in some lakes or by ciliates and/or rotifers (Güde 1988, Sanders \& Porter 1990, Weisse et al. 1990, Dolan \& Gallegos 1991).

Acknowledgements. This study was supported in part by National Science Foundation Grants BSR-8921640 and BSR9007640 (RWS), BSR-8919447 and OCE-8901005 (D.A.C.); and a post-doctoral grant from the Deutscher Akademischer Austauschdienst (U.-G.B.). We thank M. A. Moran and 2 anonymous reviewers for helpful comments. Woods Hole Oceanographic Institution Contribution Number 8102. 


\section{LITERATURE CITED}

Andersen, P., Sørensen, H. M. (1986). Population dynamics and trophic coupling in pelagic microorganisms in eutrophic coastal systems. Mar. Ecol. Prog. Ser. 33: 99-109

Azam, F., Fenchel, T., Field, J. G., Meyer-Reil, L. A., Thingstad, F. (1983). The ecological role of water-column microbes in the sea. Mar. Ecol. Prog. Ser. 10:257-263

Bennett, S. J., Sanders, R. W., Porter, K. G. (1990). Heterotrophic, autotrophic and mixotrophic nanoflagellates: seasonal abundances and bacterivory in a eutrophic lake. Limnol. Oceanogr. 35: 1821-1832

Bergh, $\varnothing .$, Børsheim, K. Y., Bratbak, G., Heldal, M. (1989). High abundance of viruses found in aquatic environments. Nature, Lond. 340: 467-429

Berninger, U.-G. (1990). The functioning and significance of microbial food webs in freshwater environments. Ph.D thesis, Free University of Berlin

Berninger, U.-G., Caron, D. A., Sanders, R. W., Finlay, B. J. (1991a). Heterotrophic flagellates of planktonic communities, their characteristics and methods of study. In: Patterson, D. J., Larsen, J. (eds.) The biology of free-living heterotrophic flagellates. Clarenden Press, Oxford, p. $39-56$

Berninger, U.-G., Finlay, B. J., Kuuppo-Leinikki, P. (1991b). Protozoan control of bacterial abundances in fresh water. Limnol. Oceanogr. 36: 139-147

Billen, G., Servais, P., Becquevort, S. (1990). Dynamics of bacterioplankton in oligotrophic and eutrophic aquatic environments: bottom-up or top-down control? Hydrobiologia 207: $37-42$

Bird, D. F., Kalff, J. (1984). Empirical relationships between bacterial abundance and chlorophyll concentration in fresh and marine waters. Can. J. Fish. Aquat. Sci. 41: $1015-1023$

Bird, D. F., Kalff, J. (1986). Bacterial grazing by planktonic lake algae. Science 231: 493-495

Bjørnsen, P. K. (1986). Bacterioplankton growth yield in continuous plankton cultures. Mar. Ecol. Prog. Ser. 30: $191-196$

Børsheim, K. Y., Bratbak, G. (1987). Cell volume to cell carbon conversion factors for a bacterivorous Monas sp. enriched from seawater. Mar. Ecol. Prog. Ser. 36: 171-175

Bratbak, G., Dundas, I. (1984). Bacterial dry matter content and biomass estimations. App. environ. Microbiol. 48: $755-757$

Brown, O. B., Evans, R. H., Brown, J. W., Gordon, H. R., Smith, R. C., Baker, K. S. (1985). Phytoplankton blooming off the U.S. east coast: a satellite description. Science 229: $163-167$

Caperon, J., Schell, D., Hirota, J., Laws, E. (1979). Ammonium excretion rates in Kaneohe Bay, Hawaii, measured by a ${ }^{15} \mathrm{~N}$ isotope dilution technique. Mar. Biol. 54: 33-40

Carlough, L. A., Meyer, J L. (1990). Rates of protozoan bacterivory in three habitats of a southeastern blackwater river. J. N. Am. benthol. Soc. 9: 45-53

Caron, D. A. (1984). The role of heterotrophic microflagellates in plankton communities. Ph.D thesis, Massachusetts Institute of Technology/Woods Hole Oceanographic Institution WHOI-84-35

Caron, D. A., Davis, P. G., Madin, L. P., Sieburth, J. McN (1982). Heterotrophic bacteria and bacterivorous protozoa on oceanic environments. Science 218: 795-797

Caron, D. A., Davis, P. G., Madin, L. P., Sieburth, J. McN (1986). Enrichment of microbial populations in macroaggregates (marine snow) from surface waters of the North Atlantic. J. mar. Res. 44: 543-565
Caron, D. A., Goldman, J. C. (1990). Protozoan nutrient regeneration. In: Capriulo, G. M. (ed.) Ecology of marine protozoa. Oxford University Press, New York, p. 283-306

Caron, D. A., Lim, E. L., Kunze, H., Cosper, E. M. Anderson, D. M. (1989). Trophic interactions between nano- and microzooplankton and the 'Brown Tide' In: Cosper, E. M., Bricelj, V. M., Carpenter, E. J. (eds.) Novel phytoplankton blooms: causes and impacts of recurrent brown tides and other unusual blooms. Springer-Verlag, Berlin, p. 265-294

Caron, D. A., Lim, E. L., Miceli, G., Waterbury, J. B., Valois, F. W. (1991). Grazing and utilization of chroococcoid cyanobacteria and heterotrophic bacteria by protozoa in laboratory cultures and a coastal plankton community. Mar. Ecol. Prog. Ser. 76: 205-217

Caron, D. A., Sanders, R. W., Stoecker, D. K. (in press) Planktonic protozoa and the microbial loop: new awareness and perspective for zooplankton research. In Tessier, A., Goulden, C. (eds.) Future directions in zooplankton population biology. Princeton University Press, Princeton

Carrick, H. J., Fahnenstiel, G. L. (1989). Biomass, sizestructure, and composition of phototrophic and heterotrophic nanoflagellate communities in lakes Huron and Michigan. Can. J. Fish. Aquat. Sci. 46: 1922-1928

Coffin, R. B., Sharp, J. H. (1987). Microbial trophodynamics in the Delaware estuary. Mar. Ecol. Prog. Ser. 41: 253-266

Cole, J. J., Findlay, S., Pace, M. L. (1988). Bacterial production in fresh and saltwater ecosystems: a cross-system overview. Mar. Ecol. Prog. Ser. 43: 1-10

Cole, J. J., Likens, G. E., Strayer, D. L. (1982). Photosynthetically produced dissolved organic carbon; an important carbon source for planktonic bacteria. Limnol. Oceanogr. 27: 1080-1090

Cosper, E. L., Carpenter, E. S., Cottrell, M. (1989). Primary productivity and growth dynamics of the 'brown tide' in Long Island embayments. In: Cosper, E. L., Bricelj, V. M., Carpenter, E. S. (eds.) Novel phytoplankton blooms: causes and impacts of recurrent brown tides and other unusual blooms. Springer-Verlag, Berlin, p. 139-158

Davis, P. G., Caron, D. A., Johnson, P. W., Sieburth, J. McN (1985). Phototrophic and apochlorotic components of picoplankton and nanoplankton in the North Atlantic: geographic, vertical, seasonal and diel distributions. Mar. Ecol. Prog. Ser. 21. 15-26

Dolan, J. R., Gallegos, C. L. (1991). Trophic coupling of rotifers, microflagellates, and bacteria during fall months in the Rhode River estuary. Mar. Ecol. Prog. Ser. 77: 147-156

Ducklow, H. W. Hill, S. M. (1985). Tritiated thymidine incorporation and the growth of heterotrophic bacteria in warm core rings. Limnol. Oceanogr. 30: 260-272

Fahnenstiel, G. L., Chandler, J. M., Carrick, H. J., Scavia, D. (1989). Photosynthetic characteristics of Lakes Huron and Michigan phytoplankton communities: P-I parameters and end-products. J. Great Lakes Res. 15: 394-407

Fenchel, T (1982a). Ecology of heterotrophic microflagelIates. II. Bioenergetics and growth. Mar. Ecol. Prog. Ser. 8: $225-231$

Fenchel, T. (1982b). Ecology of heterotrophic microflagellates. IV. Quantitative occurrence and importance as bacterial consumers. Mar. Ecol. Prog. Ser. 9: 35-42

Fenchel, T (1986). The ecology of heterotrophic microflagellates. In: Marshall, K. C. (ed.) Advances in microbial ecology. Plenum Press, New York, p. 57-97

Fuhrman, J. A., Ammerman, J. A., Azam, F. (1980). Bacterioplankton in the coastal euphotic zone: distribution, activity and possible relationships with phytoplankton. Mar. Biol. 60: $201-207$ 
Fuhrman, J. A., McManus, G. B. (1984). Do bacteria-sized marine eucaryotes consume significant bacterial production? Science 224: 1257-1260

Fuhrman, J. A., Sleeter, T. D., Carlson, C. A., Proctor, L. M. (1989). Dominance of bacterial biomass in the Sargasso Sea and its ecological implications. Mar. Ecol. Prog. Ser. 57: $207-217$

Gray, I. M. (1987). Differences between nearshore and offshore phytoplankton communities in Lake Ontario. Can. J. Fish. Aquat. Sci. 44: 2155-2163

Güde, H. (1986). Loss processes influencing growth of bacterial populations in Lake Constance. J. Plankton Res. 8 $795-810$

Güde, H. (1988). Direct and indirect influences of crustacean zooplankton on bacterioplankton in Lake Constance. Hydrobiologia 159: 63-73

Hagström, A., Azam, F., Andersson, A., Wikner, J., Rassoulzadegan, F. (1988). Microbial loop in an oligotrophic pelagic marine ecosystem: possible roles of cyanobacteria and nanoflagellates in the organic fluxes. Mar. Ecol. Prog. Ser. 49: 171-178

Kuuppo-Leinikki, P. (1990). Protozoan grazing on planktonic bacteria and its impact on bacterial population. Mar. Ecol. Prog. Ser. 63: 227-238

Landry, M. R., Haas, L. W., Fagerness, V. L. (1984). Dynamics of microbial plankton communities: experiments in Kaneohe Bay, Hawaii. Mar. Ecol. Prog. Ser. 16: 127-133

Leibold, M. A. (1989). Resource edibility and the effects of predators and productivity on the outcome of trophic interactions. Am. Nat. 134: 922-949

Malone, T. C., Ducklow, H. W. (1990). Microbial biomass in the coastal plume of Chesapeake Bay: phytoplanktonbacterioplankton relationships. Limnol. Oceanogr. 35: 296-312

McManus, G. B., Fuhrman, J. A. (1988). Control of marine bacterioplankton populations: measurement and significance of grazing. Hydrobiologia 159: 51-62

McManus, G. B., Fuhrman, J. A. (1990). Mesoscale and seasonal variability of heterotrophic nanoflagellate abundance in an estuarine outflow plume. Mar. Ecol. Prog. Ser. 61: 207-213

McManus, G. B., Peterson, W. T. (1988). Bacterioplankton production in the nearshore zone during upwelling off central Chile. Mar. Ecol. Prog. Ser. 43: 11-17

McQueen, D. J., Johannes, M. R. S., Post, J. R., Stewart, T. J., Lean, D. R. S. (1989). Bottom-up and top-down impacts on freshwater pelagic community structure. Ecol. Monogr. 59: $289-309$

Nagata, T. (1988). The microflagellate-picoplankton food linkage in the water column of Lake Biwa. Limnol, Oceanogr. 33: 504-517

Nielson, T. G., Richardson, K. (1989). Food chain structure of the North Sea plankton communities: seasonal variations of the role of the microbial loop. Mar. Ecol. Prog. Ser. 56: $75-87$

Pace, M. L. (1982). Planktonic ciliates: their distribution. abundance, and relationship to microbial resources in a monomictic lake. Can. J. Fish. Aquat. Sci. 39: 1106-1116

Pace, M. L., Funke, E. (1991). Regulation of planktonic microbial communities by nutrients and herbivores. Ecology 72: 904-914

Pace, M. L., McManus, G. B., Findlay, S. E. G. (1990). Planktonic community structure determines the fate of bacterial production in a temperate lake. Limnol. Oceanogr. 35: 795-808

Porter, K. G., Paerl, H., Hodson, R., Pace, M., Priscu, J., Riemann, B., Scavia, D., Stockner, J. (1988). Microbial interactions in lake food webs. In: Carpenter, S. R. (ed.) Complex interactions in lake communities. SpringerVerlag, New York, p. 209-227

Proctor, L. M., Fuhrman, J. A. (1990). Viral mortality of marine bacteria and cyanobacteria. Nature, Lond. 343: 60-62

Riemann, B. (1985). Potential importance of fish predation and zooplankton grazing on natural populations of freshwater bacteria. Appl. environ. Microbiol. 50: 187-193

Roman, M. R., Yentsch, C. S., Gauzens, A. L., Phinney, D. A. (1986). Grazer control of the fine-scale distribution of phytoplankton in warm-core Gulf Stream rings. J. mar. Res. 44: 795-813

Sanders, R. W., Porter, K. G. (1986). Use of metabolic inhibitors to estimate protozooplankton grazing and bacterial production in a monomictic eutrophic lake with an anaerobic hypolimnion. Appl. environ. Microbiol. 52: $101-107$

Sanders, R. W., Porter, K. G. (1988). The fate of bacteria: microbial trophodynamics in freshwater and marine habitats. EOS 69: 1112

Sanders, R. W., Porter, K. G. (1990). Bacterivorous flagellates as food resources for the freshwater crustacean zooplankter Daphnia ambigua. Limnol. Oceanogr. 35: 188-191

Sanders, R. W., Porter, K. G., Bennett, S. J., DeBiase, A. E. (1989). Seasonal patterns of bacterivory by flagellates, ciliates, rotifers, and cladocerans in a freshwater planktonic community. Limnol. Oceanogr. 34: 673-687

Scavia, D., Laird, G. A. (1987). Bacterioplankton in Lake Michigan: Dynamics, controls, and significance to carbon flux. Limnol. Oceanogr. 32: 1017-1033

Servais, P., Billen, G., Vives-Rego, J (1985). Rate of bacterial mortality in aquatic environments. Appl, environ. Microbiol. 49: 1448-1454

Sherr, B. F., Sherr, E. B., Newell, S. Y. (1984). Abundance and productivity of heterotrophic nanoplankton in Georgia coastal waters. J. Plankton Res. 6: 195-202

Sherr, B. F., Sherr, E. B., Andrew, T. L., Fallon, R. D., Newell, S. Y. (1986). Trophic interactions between heterotrophic Protozoa and bacterioplankton in estuarine water analyzed with selective metabolic inhibitors. Mar. Ecol. Prog. Ser. 32: 169-179

Sherr, E. B., Sherr, B. F, Fallon, R. D., Newell, S. Y (1986). Small, aloricate ciliates as a major component of the marine heterotrophic nanoplankton. Limnol. Oceanogr. 31: $177-183$

Sieburth, J. M., Davis, P. G. (1982). The role of heterotrophic nanoplankton in the grazing and nuturing of planktonic bacteria in the Sargasso and Caribbean Seas. Annls. Inst. océanogr., Paris 58(S): 285-296

Simon, M. (1987). Biomass and production of small and large free-living and attached bacteria in Lake Constance. Limnol. Oceanogr. 32: 591-607

Steele, J. H., Henderson, E. W. (1992). The role of predation in plankton models. J. Plankton Res. 14: 157-172

Taylor, G. T., Pace, M. L. (1987). Validity of eucaryote inhibitors for assessing production and grazing mortality of marine bacterioplankton. Appl. environ. Microbiol. 53: 119-128

Tranvik, L. J. (1988). Availability of dissolved organic carbon for planktonic bacteria in oligotrophic lakes of differing humic content. Microb. Ecol. 16: 311-322

Tranvik, L. J. (1989). Bacterioplankton growth, grazing mortality and quantitative relationship to primary production in a humic and a clearwater lake. J. Plankton Res. 11: $985-1000$

Weisse, T (1989). The microbial loop in the Red Sea: dynamics of pelagic bacteria and heterotrophic nanoflagellates. Mar. Ecol. Prog. Ser. 55: 241-250 
Weisse, T. (1990). Trophic interactions among heterotrophic microplankton, nanoplankton, and bacteria in Lake Constance. Hydrobiologia 191. 111-122

Weisse. T. (1991). The annual cycle of heterotrophic freshwater nanoflagellates: role of bottom-up versus top-down control. J. Plankton Res. 13: 167-185

Weisse, T., Müller, H., Pinto-Coelho, R. M., Schweizer, A., Springmann, D., Baldringer, G. (1990). Response of the microbial loop to the phytoplankton spring bloom in a large prealpine lake. Limnol. Oceanogr. 35: 781-794

Weisse, T., Scheffel-Möser, U. (1991). Uncouphing the microbial loop: growth and grazing loss rates of bacteria and heterotrophic nanoflagellates in the North Atlantic. Mar. Ecol. Prog. Ser. 71: 195-205

This article was presented by D. K. Stoecker, Cambridge, Maryland, USA
White, P. A., Kalff, J., Rasmussen, J. B., Gasol, J M. (1991). The effect of temperature and algal biomass on bacterial production and specific growth rate in freshwater and marine habitats. Microb. Ecol. 21: 99-118

Wikner, J., Rassoulzadegan, F., Hagström, §. (1990). Periodic bacterivore activity balances bacterial growth in the marine environment. Limnol. Oceanogr. 35: 313-324

Wright, R. T., Coffin, R. B. (1984). Measuring microzooplankton grazing on planktonic marine bacteria by its impact on bacterial production. Microb. Ecol. 10: 137-149

Wright, R. T., Coffin, R.T., Lebo, M.E. (1987). Dynamics of planktonic bacteria and heterotrophic flagellates in the Parker estuary, northern Massachusetts. Contin. Shelf Res. 7: $1383-1397$

Manuscript first received: February 6, 1992

Revised version accepted: July 29, 1992 